PACS 73.40.Gk, Lq; 73.61.Ga

Ie.V. Brytavskyi ${ }^{1}$, A.V. Tereshchenko ${ }^{\text {, }}$ V.B. Myndrul ${ }^{1}$, M.M. Pavlenko ${ }^{1,2}$, V.A. Smyntyna ${ }^{l}$

\title{
APPLICATION OF SILICON PILLAR-NANOSTRUCTURES WITH ZINC AND TITAN OXIDES COVERAGE FOR SOLAR ENERGY AND BIOSENSOR DEVICES
}

\author{
${ }^{1}$ Odessa I. I. Mechnikov National University, 2, Dvoryanskaya str., Odessa, 65082, Ukraine \\ ${ }^{2}$ NanoBioMedical Centre, Adam Mickiewicz University, Umultowska 85, Poznan, Poland \\ Phone: +380(48)7266356, Fax:+380(48)7233461, e-mail: brytav@ukr.net
}

\begin{abstract}
The work is focused on technology and characterization issues of silicon pillar nanostructures in combination with metal oxides, such as $\mathrm{ZnO}$ and $\mathrm{TiO}_{2}$, for various applications in field of biosensor and solar energy. The metal-assisted chemical etching method (MACE) modified with latex nanobeads lithography and spin-coating technique, was used to fabricate the uniform silicon nanopillar arrays. Atomic layer deposition technique (ALD) which is utilized for formation of oxide layers displays uniform coverage of the arrays and provides thin film formation independently on surface peculiarities. Therefore, it can be applied both for planar samples and 3D patterned substrates with porous media.
\end{abstract}

\section{Introduction}

The technological processing and investigation on nanostructured silicon and its composites with $\mathrm{TiO}_{2}$ and $\mathrm{ZnO}$, for use in solar energy and biosensing was performed by our group. As a basic material for the research, it was decided to use nanostructured silicon pillars, which could be fabricated with porous surface and, thus, significantly increase the effective area of the interaction, which is a crucial factor for use in biosensing approach.

Application of silicon nanopillars, especially with porous surface, can be implemented in the form of optical or electro-physical detection of molecules, including complex biomolecules.

Resent data published in literature demonstrate the advantage of the column structure compared to conventional porous substrate [1-3]. The contact area for molecule detection is fixed depending on changes in the electrical conductivity of the sensor material. The usage of arrays with parallel oriented nanopillars could reduce the signalto-noise ratio, and thereby increase the sensitivity of the sensor [4].

The next prospective application for arrays of aligned silicon nanopillars is utilization for high efficiency solar cells. The main principle is based on irradiation of radial $\mathrm{p}-\mathrm{n}$ junction obtained on silicon nanopillar coated by semiconductor material. In this approach any semiconductor may be used but silicon is an obvious choice due to low cost and relatively simple processing. In case of nanowires the quantum confinement effect is more noticeable and utilization of silicon more profitable, taking into account triviality and readiness of chemical methods, such as electrochemical and metal-assisted etching [5].

One of the prominent applications of wire/pillar based structures is a photoanode material in the process of water splitting, the separation of water into $\mathrm{H}_{2}$ and $\mathrm{O}_{2}$ under the sunlight. Currently promising option in this direction is the using of n-type silicon contact with n-type titanium dioxide, where charge carriers concentration could be increased by additional N-doping. Therefore, using of $\mathrm{TiO}_{2}$ or $\mathrm{ZnO}$ nanocomposite structure can greatly improve the quality of the photoanode.

\section{Silicon nano-pillars technology}

The process of fabrication of aligned silicon nanopillar arrays is based on the method called metal-assisted chemical etching (MACE), which was studied by our research group in recent years [6-8].

A chemical treatment of silicon implies a topdown approach and realized by silicon wafer 
etching in a solution of hydrofluoric acid and oxidizing agent (hydrogen peroxide in this research). To control the morphology of Si wafer the mask of polystyrene nanobeads (about $800 \mathrm{~nm}$ ) was deposited onto the hydrophilic silicon surface. Hydrophilicity was achieved by RCA treatment which is a standard process for cleaning of silicon wafers. After obtaining of nanobead monolayer the reactive ion etching in oxygen atmosphere was applied for convergence of the nanosphere sizes up to $600 \mathrm{~nm}$. Photoelectron lithography could be used with the same success but our approach is faster and comparatively cheaper.

A thin layer of gold was used as a catalyst. Any of the noble metals could be used in this process, but the only difference lays in the dynamics of etching and peculiarities of chemical reactions.

During the practical implementation of the MACE method, it was solved a number of technical problems related to the formation of the nanospheres monolayer, the dynamics of the etching process, and so on.

\section{The fabrication features}

SEM images show a periodic structure of nanopillar arrays fabricated onto p-type silicon wafer (Fig. 1). Due to crucial influence on the etching process, which exerts by holes, the porous nanopillars could be obtained much easier for p-type Si. However, for the n-type Si it is possible to choose conditions that can be also leading to the formation of a porous structure. For the ntype Si the peculiarities of the surface processes, including barrier properties at the interface silicon - etching solution are very important. With sufficient electron density and presence of bending zones at the interface, the etching process occurs even more intensive than for p-type silicon. These conditions are achievable by increasing the concentration of oxidizers that leads to increasing of the silicon oxidation rate.

Formation of the nanobead monolayer is the first important technological stage. It can be achieved by the spin-coating technique under high-speed rotation of the substrate. According to nanosphere size and total area of the sample this stage may be consisted of few successive steps with different rotation rates.

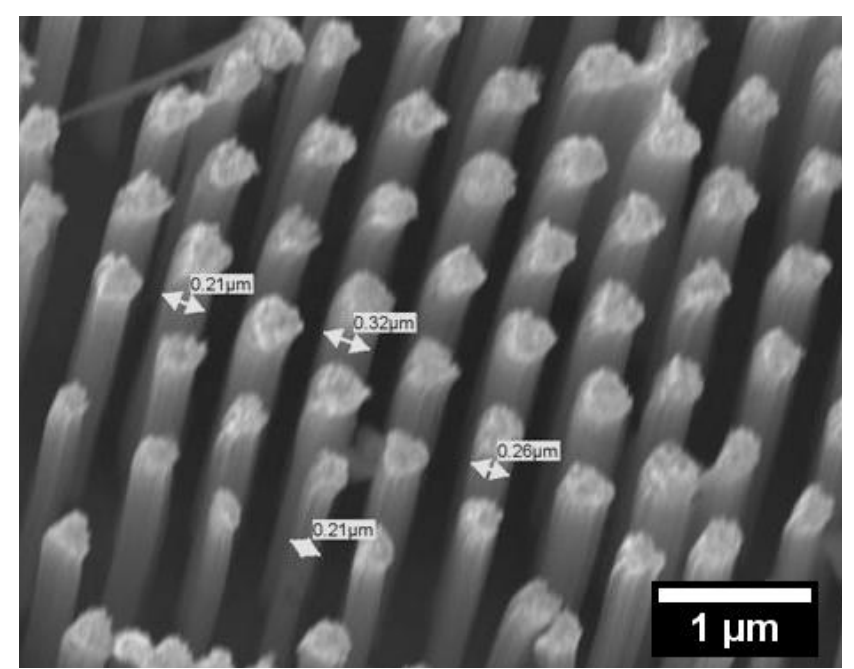

Fig 1. Nanopillar arrays fabricated on p-type silicon wafer

Figure 2 a shows SEM image of formed selfordered monolayer, the border and point defects are clearly seen. Almost defect-free film is forming after adding methanol into the nanobeads solution before the spin-coating process. The obtained film shows quite dense hexagonal packing that is suitable for further processing.

The surface of the silicon after reactive ion etching in the oxygen plasma and deposition of a gold layer by magnetron sputtering is shown in Fig. 2 b, partially sphere removed surface shows the final etching pattern. The coated area is etching faster and as a result an aligned array of silicon nanopillars is emerging. The nanospheres could be removed in an ultrasonic bath by placing the sample in ethanol.

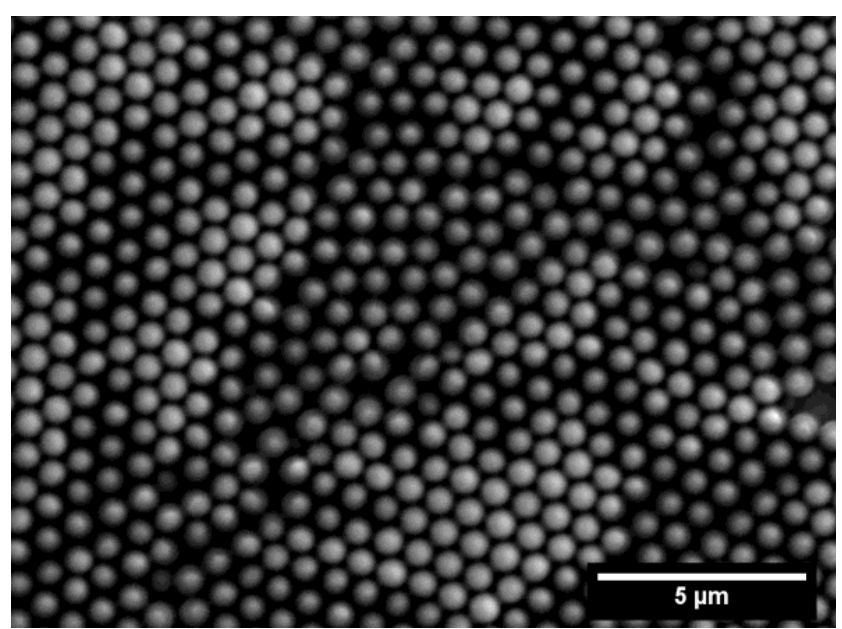

Fig. 2 a. SEM image of formed self-ordered monolayer 


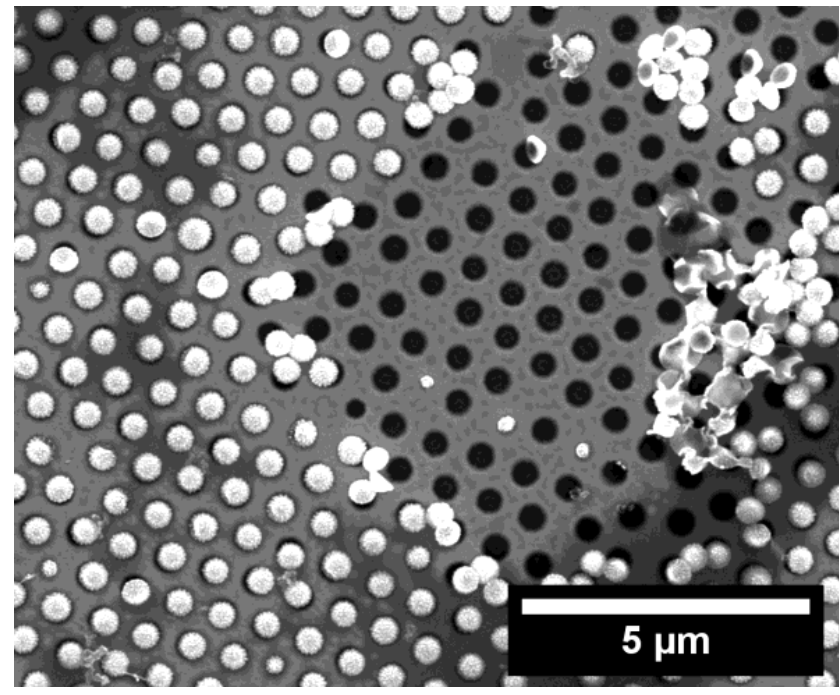

Fig. 2 b. Final etching pattern

As a result of all treatments and subsequent etching the evenly distributed hexagonal straight aligned porous nanopillar arrays are formed. By choosing the etching parameters and conditions a set of samples suitable for subsequent deposition of titanium dioxide and zinc oxide were obtained, and investigation on optical, structural and biosensing properties were performed.

For application of this type of structures in the solar energy the nanopillar arrays with bundle packed structure were obtained. These structures possess a high absorption coefficient due to additional absorption of the radiation reflected from the surface of the substrate. The advantage of such a structure over the conventional vertical arrays described in the literature and is widely studied at the present time [9].

The morphology of an individual nanopillar was investigated in details. For this purpose nanopillar arrays was decomposed in ultrasonic bath and investigated by SEM. The porous surface of a single pillar is shown in Fig. 3. The pore size is about 10-20 $\mathrm{nm}$ and relate to mesopores. Thorough investigation has shown that at least for the p-type Si a microporous structure with scale of 2 - $8 \mathrm{~nm}$ could be formed.

The ability of controlling the comprehensive morphology on pillar-structure, such as height, diameter and pore size allows us to consider these periodic nanopillar arrays as a promising material for continuing the research of silicon nanocomposite structures application for biosensor devices [10].

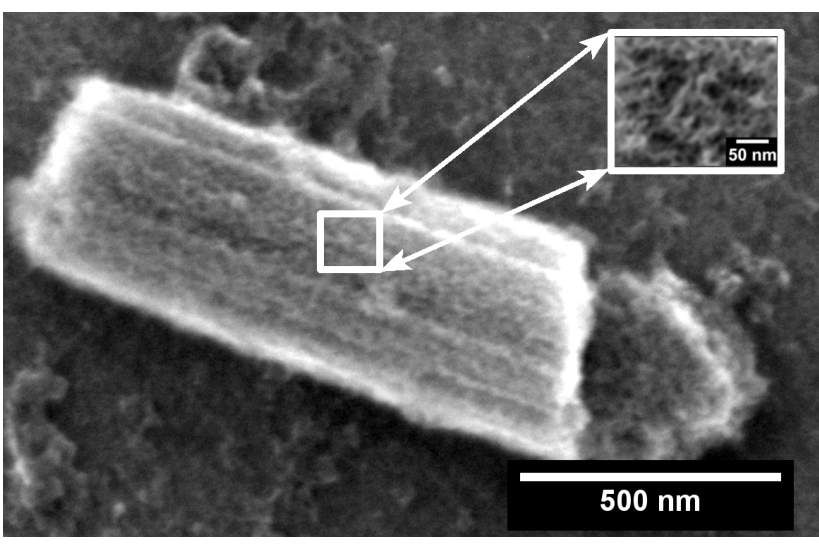

Fig. 3. Surface of a single pillar

The bulk material of the nanopillars also demonstrates a porous structure as it can be seen from "stump" of a single nanopillar (Fig. 4), also the same structure pertains to the surrounding region (silicon substrate).

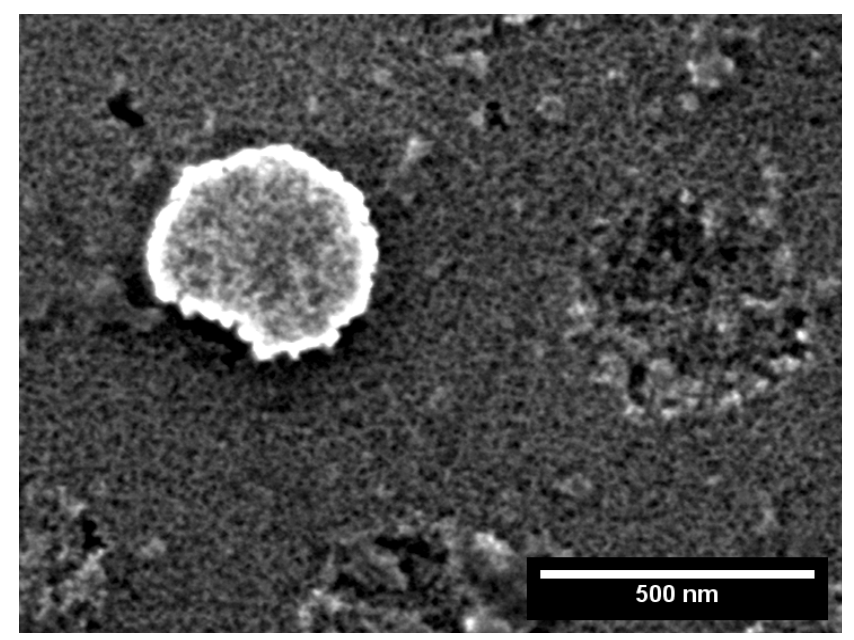

Fig. 4. Stump of a single nanopillar

\section{Characterization of metal oxide layers}

After fabrication of the aligned nanopillar arrays the next stage is a deposition of titanium dioxide and zinc oxide. Atomic layer deposition (ALD) was used for this purpose [11]. This method uses self-limiting chemical reactions between the precursors. Atomic Layer Deposition technique provides even thin film deposition and can be applied for planar surface, 3D patterned substrate and porous structure [7, 12]. Processing per cycle takes time of few seconds (precursor sputtering in the chamber for less than a second). Typical ALD process involves three stages: inlet 
of first precursor, chemical reaction to the surface and blowing off the chamber with nitrogen. Then second precursor goes through the stages the same order.

A complex nanocomposite structure is forming after the deposition of titanium dioxide on the porous nanopillar arrays. At a certain pillar's height and thickness of titanium dioxide layer occurs a mechanical deformation of the array (Fig. 5). In order to investigate this process the $\mathrm{TiO}_{2}$ layer was deposited in the range of 150 to 500 ALD cycles, the equivalent growth rate for smooth surface is about $0.2 \AA$ per cycle. Mechanical changes in the pillar arrays structure takes place at sufficiently large height and could lead to destruction of the too high pillars. As well a crucial destruction influence on the lengthy pillar arrays occurs during the etching process due to hydrodynamic forces.

Such a complex composite system is very interesting for future research, including features of quantum confinement effects and application in biosensor devices.

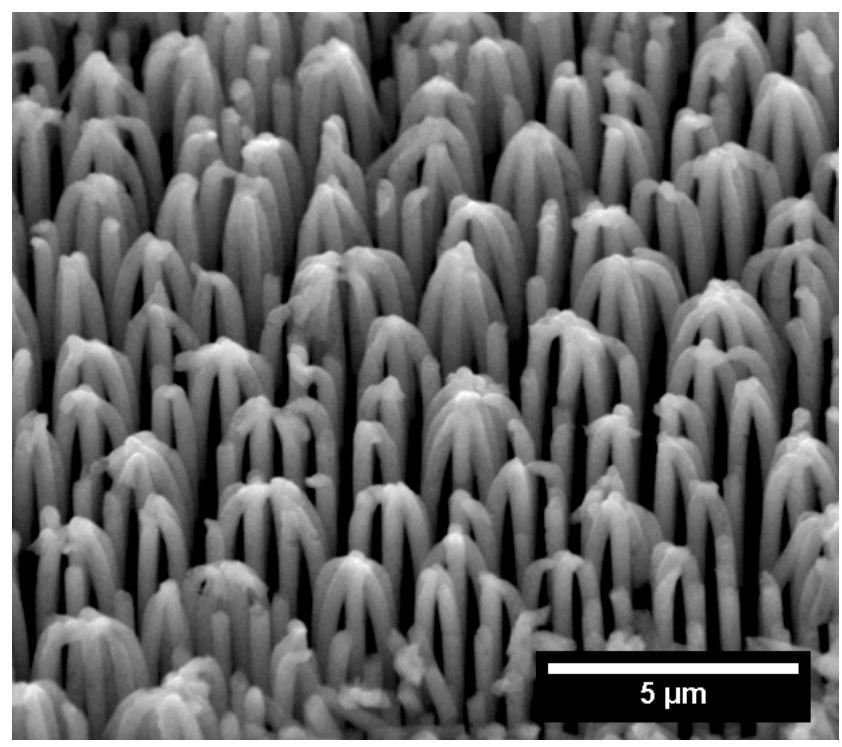

Fig. 5. Mechanical deformation of the array

By filling the space between pillars, $\mathrm{TiO}_{2}$ forms an amorphous photoactive layer, which provides an effective light harvesting on the heterojunction interface. During the ALD process, $\mathrm{TiO}_{2}$ quite deeply penetrates into the pores and additional annealing process induces a complex polycrystalline structure in the matrix of porous silicon.

The similar nanocomposite based on $\mathrm{ZnO}$ was also investigated for biosensor application. The principle of operation of the biosensor is based on immobilization of the biosensitive layer on the surface of zinc oxide $[8,10]$. Presence of the detected substance could be estimated through reflectivity or luminescence spectra due to surface plasmon resonance effect under UV irradiation. Probes of $\mathrm{ZnO} / \mathrm{Si}$ nanolaminates were fabricated for investigation of this process. Deposition of 250 and $500 \mathrm{ZnO}$ ALD cycles were implemented onto flat silicon substrate. Obtained probes have shown a good stability and high adhesion, therefore further investigation of mentioned composite structures seems to be prospective.

\section{Results and conclusion}

Thus, an important problem was resolved identification and optimization of new and known technological mechanisms in nanosilicon forming processes that have influence on the optical, structural and surface properties of obtained $\mathrm{Si} /$ $\mathrm{ZnO}$ and $\mathrm{Si} / \mathrm{TiO}_{2}$ nanocomposites as a result of the influence of components interaction and external factors with the aim of stabilization of the properties of materials based on nanocomposite materials.

The technology of porous silicon nanopillars and new nanocomposites based on the method of using chemical nonelectrolytic etching and atomic layered deposition was developed. Structural characteristics of the obtained complex nanocomposite structures were determined by using of SEM equipment.

On the base of the described approach of nanosilicon composites in modern electronic industry the properties of existing photosensitive, gassensitive and other media can be improved, and also the improvement of operating parameters of devices on the base of nanopillar Si with a simultaneous reduction in the cost of raw materials which may lead to lower the prices of mentioned devices. The research results can be used in the development of applied sections of surface physics, semiconductor physics, materials science, micro- and nanoelectronics. Technological optimization results can be used in developed processes to create nanostructures on silicon. Theoretical information and new fundamental results on optical and electrical properties of nanoscale systems, such as studied Si nanopillars, give the 
way to perform the basic properties research of nano-Si composites, their practical use and creation of new devices electronic technology on its base.

\section{Reference}

[1] H. S. Wasisto, S. Merzsch, A. Stranz, A. Waag, E. Uhde, T. Salthammer and E. Peiner, Sens. Actuators, B, 2013, 189, 146-156.

[2] B. D. Choudhury, R. Casquel, M. J. Banuls, F. J. Sanza, M. F. Laguna, M. Holgado, R. Puchades, A. Maquieira, C. A. Barrios and S. Anand,Opt. Mater. Express, 2014, 4, 1345-1354.

[3] M. Kandziolka, J. J. Charlton, I. I. Kravchenko, J. a. Bradshaw, I. a. Merkulov, M. J. Sepaniak and N. V. Lavrik, Anal. Chem., 2013, 85, 90319038.

[4] Y. J. Hwang, A. Boukai and P. Yang, Nano Lett., 2009, 3, 410-415.

[5] H. Lin, M. Fang, H.-Y. Cheung, F. Xiu, S. Yip, C.-Y. Wong and J. C. Ho, RSC Adv., 2014, 4, 50081-50085.

[6] I. Iatsunskyi, M. Pavlenko, R. Viter, M. Jancelewicz, G. Nowaczyk, I. Baleviciute, K. Załęski, S. Jurga, A. Ramanavicius, V. Smyntyna, The Journal of Physical Chemistry C 119 (2015) 7164-7171
[7] I. Iatsunskyi, M. Pavlenko, G. Nowaczyk, V. Fedorenko, S. Jurga, V. Smyntyna / Optic. - 2015, 126, 1650-1655

[8] A.V. Tereshchenko, V.A. Smyntyna, I.P. Konup, S.A. Geveliuk, M.F. Starodub, Springer Science+Business Media Dordrecht 2016, Nanomaterials for Security, NATO Science for Peace and Security Series A: Chemistry and Biology, 2016

[9] Dong-Myeong Shin, Hye Ji Han, WonGeun Kim, Eunjong Kim, Chuntae Kim, Suck Won Hong, Hyung Kook Kim, Jin-Woo Oh and Yoon-Hwae Hwang, Energy Environ. Sci., 2015,8, 3198-3203

[10] A. Tereshchenko, M Bechelany, R. Viter, V. Khranovskyy, V. Smyntyna, N. Starodub, R. Yakimova, Sensors and Actuators B 229 (2016) 664-677.

[11] Y. Yan, D. Wang and P. Schaaf, Dalton Trans., 2014, 43, 8480-8485.

[12] R. Viter, I. Iatsunskyi, V. Fedorenko, S. Tumenas, Z. Balevicius, A. Ramanavicius, S. Balme, M. Kempin, G. Nowaczyk, S. Jurga and M. Bechelany, J. Phys. Chem. C, 2016,120, 5124-5132.

Article received on May 2017

PACS 73.40.Gk, Lq; 73.61.Ga

Ie. V. Brytavskyi, A. V. Tereshchenko, V. B. Myndrul, M. M. Pavlenko, V. A. Smyntyna

\section{SILICON NANOPILLARS FORMING AND COVERING BY Zn AND Ti OXIDES FOR SOLAR ENERGY APPLICATIONS AND BIOSENSORICS}

\section{Summary}

The work is focused on technology and characterization issues of silicon pillar nanostructures in combination with metal oxides, such as $\mathrm{ZnO}$ and $\mathrm{TiO}_{2}$, for various applications in field of biosensor and solar energy. The metal-assisted chemical etching method (MACE) modified with latex nanobeads lithography and spin-coating technique, was used to fabricate the uniform silicon nanopillar arrays. Atomic layer deposition technique (ALD) which is utilized for formation of oxide layers displays uni- 
form coverage of the arrays and provides thin film formation independently on surface peculiarities. Therefore, it can be applied both for planar samples and 3D patterned substrates with porous media.

Key words: nanopillars, atomic layer deposition, nanocomposites

УДК 73.40.Gk, Lq; 73.61.Ga

Є. В. Бритавський, А. В. Терещзенко, В. Б. Миндрул, М. М. Павленко, В. А. Сминтина

\title{
ФОРМУВАННЯ КРЕМНІЕВИХ НАНО-ПІЛЛАРСІВ ТА ПОКРИТТЯ ЇХ ОКСИДАМИ ЦИНКУ ТА ТИТАНУ ДЛЯ ВИКОРИСТАННЯ В СОНЯЧНІЙ ЕНЕРГЕТИЦІ ТА БІОСЕНСОРИЦ
}

\begin{abstract}
Анотація
Робота присвячена технології і характеризації кремнієвих наноструктур в поєднанні 3 покриттям оксидами металів для різних застосувань в біосенсориці і сонячній енергетиці. У статті описується спосіб неелектролітичного травлення, модифікованого використанням шару наносфер на підкладці, сформованого методом поверхневого центрифугування. Метод атомно-шарового осадження, який використовувався для формування оксидів на наноструктурах, демонструє утворення рівномірного шару і не залежить від геометрії підкладки, тому він може застосовуватися як для плоских зразків, так і для підкладок з тривимірною структурою і з пористими шарами.
\end{abstract}

Ключові слова: наностовбчик, атомно-шарове осадження, нанокомпозит

УДК 73.40.Gk, Lq; 73.61.Ga

Е. В. Бритавский, А. В. Терещенко, В. Б. Мындрул, Н. Н. Павленко, В. А. Смынтына

\section{ФОРМИРОВАНИЕ КРЕМНИЕВЫХ НАНО-ПИЛЛАРСОВ И ПОКРЫТИЯ ИХ ОКСИДАМИ ЦИНКА И ТИТАНА ДЛЯ ИСПОЛЬЗОВАНИЯ В СОЛНЕЧНОЙ ЭНЕРГЕТИКЕ И БИОСЕНСОРИКЕ}

\footnotetext{
Аннотация

Работа посвящена технологии и характеризации кремниевых наноструктур в сочетании с оксидами металлов для различных применений в биосенсорике и солнечной энергетике. В статье описывается способ неэлектролитического травления, модифицированного использованием слоя наносфер на подложке, сформированного методом поверхностного центрифугирования. Метод атомно-слоевого осаждения, который использовался для формирования оксидов на наноструктурах, демонстрирует образование равномерного слоя и не зависит от геометрии подложки, поэтому он может применяться как для плоских образцов, так и для подложек с трехмерной структурой и с пористыми слоями.

Ключевые слова: наностолбик, атомно-слоевое осаждение, нанокомпозит
} 